\title{
Tectonic structure and evolution of East Antarctica in the light of knowledge about supercontinents
}

\author{
G. E. Grikurov and E. V. Mikhalskii \\ All-Russia Research Institute of the World Ocean Geology and Mineral Resources, St. Petersburg
}

\begin{abstract}
This paper is based on the study of the new geological, isotopic, and geochemical data that were obtained in the last years on the igneous and metamorphic rocks of East Antarctica, dated from Late Mesoproterozoic to Early Paleozoic. This period of its geological history is believed, based on plate-tectonic paleoreconstructions, to include, first, the origin and breakup of the hypothetical Rodinia Supercontinent and, later, the formation of a new supercontinent, Gondwana. Our review and critical study of extensive foreign literature, as well as the results of our own field and laboratory studies of crystalline rocks from the East Antarctica crystalline basement, suggested a different idea: the supercontinental lithospheric block, including the continents of the Gondwana group, had remained intact throughout the Proterozoic, and perhaps throughout the whole of the Precambrian. Intensity-variable extension pulses, which acted on that primary continental lithosphere, might have caused the origin of some local ocean openings, yet did not result, up to the end of the Mesozoic, in the complete breakup of this sialic megablock with any large-scale spreading development.
\end{abstract}

\section{Introduction}

Since the earliest Russian expeditions to Antarctica, the tectonic structure and evolution of the sixth continent remained in the sphere of the interests of Russian investigators [Egiazarov, 1969; Klimov et al., 1964; Ravich and Grikurov, 1970; Ushakov and Khain, 1965; Voronov, 1960]. The result of the early activity of Soviet Antarctic geologists was the first Russian tectonic map of Antarctica, which was printed as an independent edition more than 20 years ago [Grikurov, 1978]. Since then, huge amounts of geological and analytical data have been accumulated, the interpretation of which in the light of the modern geodynamic concepts enabled us to advance new models for the evolution of the region without introducing any essential changes into the boundaries of the conventional major tectonic provinces.

The largest of them is the East Antarctic Precambrian Craton which consists of a shield, expressed morphologically as the positive forms of the bedrock topography and, hence,

Copyright 2002 by the Russian Journal of Earth Sciences.

Paper number TJE02099.

ISSN: 1681-1208 (online)

The online version of this paper was published 2 July 2002. URL: http://rjes.wdcb.ru/v04/tje02099/tje02099.htm exposed partially in superice rocks, and the area of the inferred development of platform rocks, hidden under the ice, corresponding to the negative forms of the bedrock topography (Figure 1).

The rocks of the crystalline basement, outcropping in the shield, can be classified as those of two major types of tectonic elements. One of them is represented by the cores of early stabilization: Archean-Paleoproterozoic granulitegneiss and granite-greenstone areas, or cratons [Kamenev, 1993]. The best known are the gneiss-granulite craton of Enderbi Land, dominated by an enderbite-charnockite associations, similar to those known from the Hindustan Peninsula, and a granite-greenstone craton in western Queen Maud Land, closely resembling the Cape Vaal rocks of South Africa. Smaller and usually less known ancient cores are known in some other coastal and inland regions of East Antarctica.

The structural elements of another type, which are the subject of this paper, encircle and separate the Early Precambrian cratons and, hence, are combined, at the presentday knowledge, into the collective notion of a Proterozoic mobile belt, even though, actually, it is possible that a number of intercratonic mobile belts and zones originated there during various periods of the Proterozoic Era. This belt (or belts) is marked by the most intensive manifestations of Early Paleozoic tectonic activity. The Proterozoic and Early Paleozoic metamorphic and igneous processes that operated 


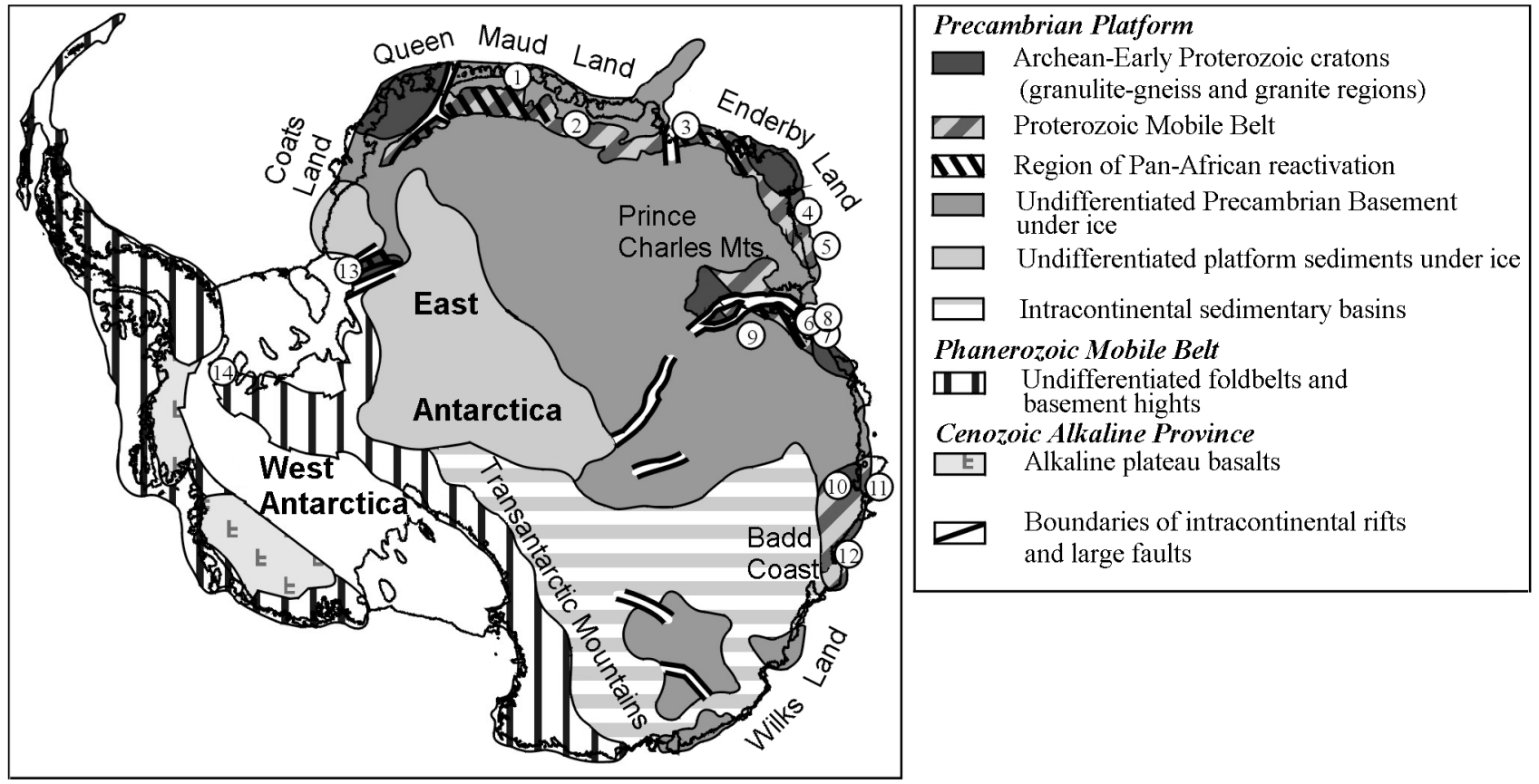

Figure 1. Schematic tectonic map of Antarctica.

The figures denote: 1 - Shirmakher Oasis, 2 - Sör-Ronnane Mountains, 3 - Lützow-Holm Gulf, 4 - Kemp Coast, 5 - Mawson Coast, 6 - Larsemann Oasis, 7 - Rëuer Ils., 8 - Pryuds Gulf, 9 - Grove nunataks, 10 - Denman Glacier, 11 - Bunger Oasis, 12 - Windmill Ils., 13 - Shackleton Range, 14 - Haag nunataks.

within the mobile belt are usually interpreted as the imprints of collision-related tectonic and thermal environments that arose at the margins of the Antarctic and other continental masses during their amalgamation into supercontinents of the geological past: Mesoproterozoic Rodinia [Dalziel, 1991; Hoffman, 1991] and late Neoproterozoic-Early Paleozoic Gondwana [Kroner, 1993; Rogers et al., 1995; Shackleton, 1993, 1996].

The aim of this study was to generalize and analyze the extensive isotope-geochemical, primarily $\mathrm{U}-\mathrm{Pb}$ and $\mathrm{Sm}-\mathrm{Nd}$, data obtained during the last 10-15 years both by foreign and Russian investigators (see Table 1), to analyze the compositions of the rocks of the Proterozoic mobile belt, to time and interpret geodynamically the main periods of the tectonic evolution of the mobile belt, using these data, and to review critically the existing views on the formation of the supercontinents.

\section{Lithology and Isotope-Geochemical Characteristics of Rocks from the Proterozoic Mobile Belt in the Key Regions of East Antarctica}

The western part of Queen Maud Land is composed mainly of metamorphic sediments, as well as orthogneisses (including those of tonalite composition) and amphibolites referring to a calc-alkalic series of a $\mathrm{Na}$ speciation. The geo- chemical data suggest the juvenile origin of the rocks from a relatively young (Mesoproterozoic) material $\left(\varepsilon_{\mathrm{Nd}}(i)=+3-6\right.$ (gneiss) or $-1.5-0$ (granitoids), $\left.\mathrm{Sr}_{\mathrm{i}}=0.702-0.705\right)$ in the geodynamic conditions of a magmatic arc or at the continental margin, mostly between 1200 and 1150 million years ago, although the oldest of the tonalite gneisses were dated $1400 \mathrm{Ma}$. The model $\mathrm{Sm}-\mathrm{Nd}$ age of the rocks $\left(\mathrm{T}_{\mathrm{DM}}\right)$ was found to be 1.8-1.4 Ga; the rocks in the northeastern areas were dated 2.4-1.9 Ga [Hunter et al., 1991; Wareham et al., 1998]. The rocks were deformed and metamorphosed to an amphibolite facies at a boundary between 1150 and 1000 million years [Groenewald et al., 1995]. The Pan-African processes are manifested irregularly in this region. No thermal effects of this age were found in the extreme western areas which are separated by a NE-striking very wide regional blastomilonite zone from the areas where Pan-African processes grow in intensity eastward. The $\mathrm{K}-\mathrm{Ar}$ and $\mathrm{Ar}-\mathrm{Ar}$ data suggest the Pan-African age of the deformations, though there are some scarce "relict" datings of Neoproterozoic age (ca. $800 \mathrm{Ma}$ ), this indicating the inherited type of this regional deformation zone [Jacobs et al., 1995]. This area includes folded quartzite and conglomerates of Late Neoproterozoic age (Urfjella Group), not less than $1650 \mathrm{~m}$ thick. It is supposed that these rocks accumulated in a high-energy coastalmarine environment. The origin of a shallow-sea basin is believed to have been associated with the transpressure conditions caused by the reactivation of a consolidated Mezoproterozoic mobile belt.

The central part of Queen Maud Land shows a wide development of highly metamorphosed sediments, mafic gran- 

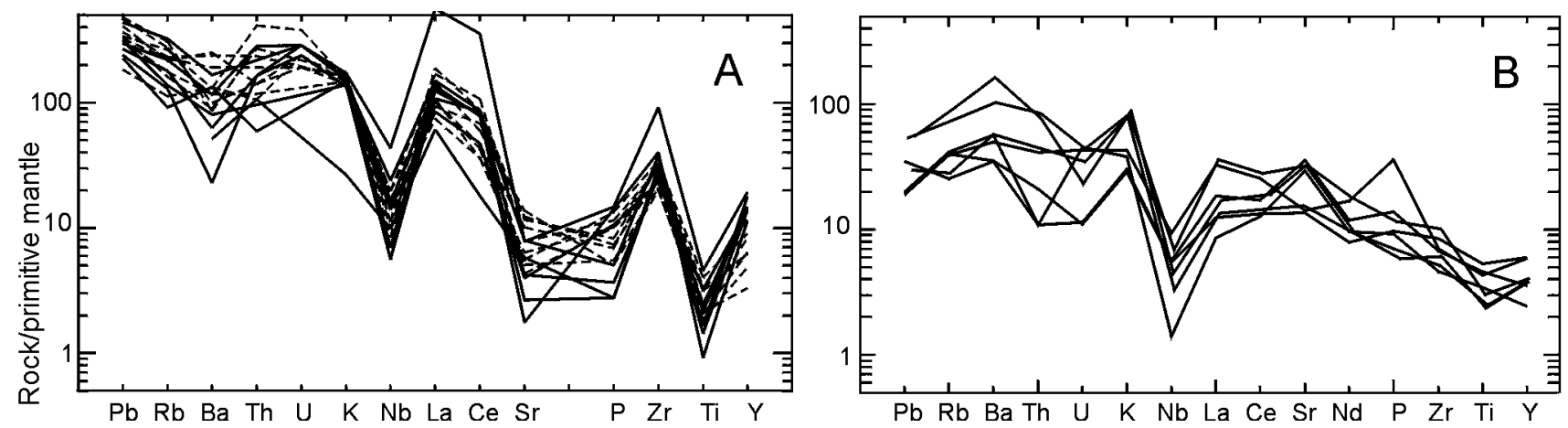

Figure 2. Diagrams of normalized microcomponent contents for metamorphic rocks from central Queen Maud Land (A: solid lines are orthogneisses of plutonic origin; dash lines are orthogneisses of supposed volcanic origin) and the Fisher rock complex from the Prince Charles Mountains (B). All contents were normalized for primitive mantle (after [Sun and McDonough, 1989]).

ulites, and orthogneisses. The compositions of these rocks suggest their origin mostly under intraplate conditions with a limited contribution of a deep mantle material. Most of these rocks are enriched both in LILE elements (Rb, Ba, Th, $\mathrm{K}$ ) and light REE, and also in some HFSE elements (Zr, Y), this being responsible for the saw-tooth pattern of the lines of their normalized contents (Figure 2A). The orthogneisses generally differ in their microcomponent contents from common orogenic granitoids (Figure 3) and are closer to A-type granitoids. These bodies are of syntectonic origin and were intruded some 1130-1080 Ma ago [Jacobs et al., 1998]. The model $\mathrm{Sm}-\mathrm{Nd}$ age of the rocks $\left(\mathrm{T}_{\mathrm{DM}}\right)$ was placed within 2.0-1.8 Ga [Jacobs et al., 1998; Mikhalsky et al., 1997], although some rocks, especially those from the Shirmaher Oasis, were dated 1.4-1.2 Ga [Kämph and Höhndorf, 1995]. The culmination events of the superimposed tectogenesis,

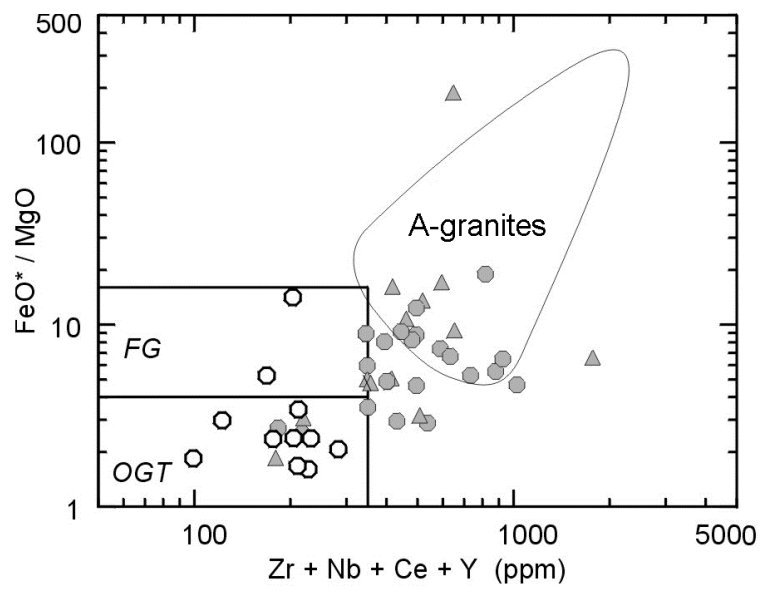

Figure 3. Positions of the metamorphic rocks of central Queen Maud Land (solid circles - orthogneiss of plutonic origin, triangles - orthogneiss of inferred volcanic origin) and of the Fisher rocks from the Prince Charles Mountains (open circles) in the $\mathrm{Zr}+\mathrm{Nb}+\mathrm{Ce}+\mathrm{Y}-\mathrm{FeO}^{*} / \mathrm{MgO}$ diagram (after [Whalen et al., 1987]). OGT - orogenic granitoids; FG - fractionated granitoids. accompanied by metamorphism of a high amphibolite to a granulite facies, granite generation, and the formation of mylonitization zones (and possibly of penetration schistosity), have been dated $700,590-570$, and 530-515 million years [Jacobs et al., 1998; Mikhalsky et al., 1997; and our unpublished data]. Large anorthosite--mangerite-charnockite plutons were intruded ca. 600 and 510 million years ago. Apparently, the dikes of calc-alkalic lamprophyre, developed in the Shirmaher Oasis and dated Ordovician, were associated paragenetically with the final events of the charnockite magmatism.

The eastern part of Queen Maud Land is distinguished by the development of granulite-facies migmatites, mafic granulites, gneisses, tonalite orthogneisses, and crystalline schists of the almandine amphibolite facies, as well as crystalline schists of the epidotesamphibolite and greenschist facies of metamorphism. The emplacement of the tonalite orthogneisses was dated $1017 \pm 13 \mathrm{Ma}$ by a U-Pb (SHRIMP) method, and the metamorphism of the felsic gneisses was dated $1130-1030 \mathrm{Ma}$ by a Rb-Sr method. The peak conditions of the metamorphism and deformation had been achieved in this region significantly later, 720-680 million years ago (Rb-Sr data [Shibata et al., 1986]) and/or 550-530 million years ago (U-Pb data [Shiraishi et al., 1992]). Based on the composition of the metamorphic rocks, some investigators suggest the substantial contribution of mantle derived rocks. In particular, the mafic granulites and migmatized felsic gneisses in the Sör Ronnane Mountains, East Antarctica, have been interpreted as metavolcanics with a calc-alkalic evolution trend (Figure 4), which had been emplaced under the conditions of a volcanic arc and a continental magmatic arc [Osanai et al., 1992]. Their model Sm-Nd age $\left(\mathrm{T}_{\mathrm{DM}}\right)$ was found to be $1.4-1.3 \mathrm{Ga}$ [Shiraishi and Kagami, 1992]. The U-Pb (SHRIMP) isotopic study of the rocks from the Lützow-Holm Complex [Shiraishi et al., 1992] yielded younger ages around $1000 \mathrm{Ma}$, compared to some other regions of East Antarctica. The SHRIMP data are believed to mark the main stage of the tectogenesis which had been responsible for the plastic deformation of the rocks and the formation of penetration schistosity in the time interval of 550-530 million years. 
Table 1. Selected geochronological data for rocks from the key areas of the Precambrian Platform and the mobile belt of Antarctica

\begin{tabular}{|c|c|c|c|c|}
\hline Rock & Method & Date, Ma & Interpretation & Reference \\
\hline \multicolumn{5}{|l|}{ Antarctic Craton } \\
\hline \multicolumn{5}{|l|}{ Precambrian basement } \\
\hline \multicolumn{5}{|c|}{ Shackleton Range } \\
\hline Ophiolite & $\mathrm{K}-\mathrm{Ar} \mathrm{Hbl}$ & $\sim 500$ & Suturing (?) & [Talarico et al., 1999] \\
\hline Orthogneiss & $\mathrm{U}-\mathrm{Pb} \mathrm{Zr}$ & $1715 \pm 6$ & Migmatization & [Brommer et al., 1999] \\
\hline Orthogneiss & $\mathrm{U}-\mathrm{Pb} \mathrm{Zr}$ & $2328 \pm 47$ & Intrusion & [Brommer et al., 1999] \\
\hline Schist, gneiss & $\mathrm{Sm}-\mathrm{Nd}\left(\mathrm{T}_{\mathrm{DM}}\right)$ & $2200-1800$ & Primary crust formation & [Pankhurst et al., 1983] \\
\hline & $\mathrm{Rb}-\mathrm{Sr}\left(\mathrm{T}_{\mathrm{UR}}\right)$ & $2700-2400$ & & $\begin{array}{l}\text { [Pankhurst et al., 1995] } \\
\text { [Brommer et al., 1999] }\end{array}$ \\
\hline \multicolumn{5}{|l|}{ Proterozoic mobile belt } \\
\hline \multicolumn{5}{|l|}{ Coats Land } \\
\hline Rhyolite & $\mathrm{U}-\mathrm{Pb} \mathrm{Zr}$ & $112 \pm 4$ & Volcanism & [Gose et al., 1997] \\
\hline Silicic igneous rocks & $\mathrm{Sm}-\mathrm{Nd}\left(\mathrm{T}_{\mathrm{DM}}\right)$ & $1300-1200$ & Primary crust formation & [Wareham et al., 1998] \\
\hline \multicolumn{5}{|l|}{ Western Queen Maud Land } \\
\hline Mylonite & $\mathrm{Ar}-\mathrm{Ar} \mathrm{Hbl}$ & $531 \pm 6$ & Deformation & [Jacobs et al., 1997 \\
\hline Gneiss & Rb-Sr WR & $1015 \pm 24$ & Metamorphism & [Moyes and Barton, 1990 \\
\hline S-type granitoids & $\mathrm{U}-\mathrm{Pb} \mathrm{Zr}(\mathrm{SH})$ & $1127 \pm 12$ & $\begin{array}{l}\text { Syntectonic intrusion, } \\
\text { deformation }\end{array}$ & [Harris et al., 1995] \\
\hline Metatonalite & $\mathrm{U}-\mathrm{Pb} \mathrm{Zr}(\mathrm{SH})$ & $1130 \pm 17$ & $\begin{array}{l}\text { Syntectonic intrusion, } \\
\text { deformation }\end{array}$ & [Jacobs et al., 1999] \\
\hline Gneiss & Rb-Sr WR & $1183 \pm 27$ & Metamorphism & [Moyes and Barton, 1990] \\
\hline Gneiss & $\mathrm{U}-\mathrm{Pb} \mathrm{Zr}(\mathrm{SH})$ & $\sim 1400$ & $\begin{array}{l}\text { Syntectonic intrusion, } \\
\text { deformation }\end{array}$ & [Grantham et al., 1999] \\
\hline Gneiss & $\mathrm{Sm}-\mathrm{Nd}\left(\mathrm{T}_{\mathrm{DM}}\right)$ & $\begin{array}{l}1800-1400 \\
2400-1900\end{array}$ & Primary crust formation & $\begin{array}{l}{[\text { Hunter et al., } 1991]} \\
{[\text { Wareham et al., 1998] }}\end{array}$ \\
\hline \multicolumn{5}{|l|}{ Central Queen Maud Land } \\
\hline Charnockite & $\mathrm{U}-\mathrm{Pb} \mathrm{Zr}$ & $512 \pm 2$ & Intrusion & [Mikhalsky et al., 1997 \\
\hline Orthogneiss & $\mathrm{U}-\mathrm{Pb} \mathrm{Zr}(\mathrm{SH})$ & $\sim 540-515$ & $\begin{array}{l}\text { Amph.-granul. facies } \\
\text { metamorphism }\end{array}$ & $\begin{array}{l}{[\text { Jacobs et al., } 1998]} \\
{[\text { Mikhalsky et al., } 1997]}\end{array}$ \\
\hline Orthogneiss & $\mathrm{U}-\mathrm{Pb} \mathrm{Zr}(\mathrm{SH})$ & $530 \pm 8$ & $\begin{array}{l}\text { Syntectonic intrusion, } \\
\text { deformation }\end{array}$ & {$[$ Jacobs et al., 1998] } \\
\hline I-and A-type orthogneiss & $\mathrm{U}-\mathrm{Pb} \mathrm{Zr}(\mathrm{SH})$ & $1076 \pm 14$ & $\begin{array}{l}\text { Syntectonic intrusion, } \\
\text { deformation } \\
\text { Granul. facies metamorphism }\end{array}$ & [Jacobs et al., 1998] \\
\hline Gneiss & $\mathrm{U}-\mathrm{Pb} \mathrm{Zr}(\mathrm{SH})$ & $1130 \pm 12$ & Magmatism, deformation & [Jacobs et al., 1998] \\
\hline Gneiss & Sm-Nd $\left(\mathrm{T}_{\mathrm{DM}}\right)$ & $\begin{array}{l}1400-1200 \\
2000-1800\end{array}$ & Primary crust formation & $\begin{array}{l}{[\text { Jacobs et al., } 1998]} \\
{[\text { Mikhalsky et al., 1997] }} \\
{[\text { Kämph and Höhndorf, 1995] }}\end{array}$ \\
\hline \multicolumn{5}{|l|}{ Eastern Queen Maud Land } \\
\hline Gneiss & $\mathrm{U}-\mathrm{Pb} \mathrm{Zr}(\mathrm{SH})$ & $550-530$ & Granul. facies metamorphism & [Shiraishi et al., 1992] \\
\hline Tonalite orthogneiss & $\mathrm{U}-\mathrm{Pb} \mathrm{Zr}(\mathrm{SH})$ & $1017 \pm 13$ & $\begin{array}{l}\text { Syntectonic intrusion, } \\
\text { deformation }\end{array}$ & [Shiraishi et al., 1992] \\
\hline Gneiss & Rb-Sr WR & $1130-1030$ & Metamorphism & [Shibata et al., 1986] \\
\hline Gneiss & $\mathrm{Sm}-\mathrm{Nd}\left(\mathrm{T}_{\mathrm{DM}}\right)$ & $1400-1300$ & Primary crust formation & [Shiraishi and Kagami, 1992] \\
\hline
\end{tabular}


Table 1. Continued

\begin{tabular}{|c|c|c|c|c|}
\hline Rock & Method & Date, Ma & Interpretation & Reference \\
\hline \multicolumn{5}{|c|}{ Northern Prince Charles Mountains } \\
\hline A-type granite, pegmatite & $\mathrm{U}-\mathrm{Pb} \mathrm{Zr}$ & $\sim 500$ & Intrusion & [Manton et al., 1992] \\
\hline Gneiss & $\mathrm{U}-\mathrm{Pb} \mathrm{Zr}(\mathrm{SH})$ & 990 & $\begin{array}{l}\text { Deformation, amph.-gran. } \\
\text { metamorphism }\end{array}$ & [Boger et al., 2000] \\
\hline Felsic and mafic schists & $\begin{array}{l}\text { U-Pb Zr, } \\
\mathrm{U}-\mathrm{Pb} \mathrm{Zr}(\mathrm{SH})\end{array}$ & $\sim 1300$ & Volcanism (?) & $\begin{array}{l}{[\text { Beliatsky et al., 1994] }} \\
{[\text { Kinny et al., 1997] }}\end{array}$ \\
\hline Felsic schist & Sm-Nd $\left(\mathrm{T}_{\mathrm{DM}}\right)$ & $\begin{array}{l}1600-1400 \\
2200-1500\end{array}$ & Primary crust formation & $\begin{array}{l}{[\text { Mikhalsky et al. }, 1996]} \\
{[\text { Manton et al. }, 1992]} \\
{[\text { Zhao et al., } 1997}\end{array}$ \\
\hline \multicolumn{5}{|c|}{ Pryuds Gulf coast } \\
\hline S-type granite & $\mathrm{U}-\mathrm{Pb} \mathrm{Zr}$ & $\sim 540$ & $\begin{array}{l}\text { Syntectonic intrusion, } \\
\text { deformation } \\
\text { Granul. facies metamorphism }\end{array}$ & [Zhao et al., 1995] \\
\hline Orthogneiss & U-Pb Zr (SH) & $\sim 1000$ & $\begin{array}{l}\text { Syntectonic intrusion, } \\
\text { metamorphism, deformation }\end{array}$ & [Kinny et al., 1993] \\
\hline Gneiss & Sm-Nd $\left(\mathrm{T}_{\mathrm{DM}}\right)$ & $\begin{array}{l}2200-1600 \\
3300-3100\end{array}$ & Primary crust formation & $\begin{array}{l}{[\text { Kinny et al., } 1993]} \\
{[\text { Zhao et al., 1995] }}\end{array}$ \\
\hline \multicolumn{5}{|c|}{ Denman Glacier-Bunger Oasis Region } \\
\hline Gneiss & $\mathrm{U}-\mathrm{Pb} \mathrm{Zr}$ & $1190 \pm 15$ & Granul. facies metamorphism & [Sheraton et al., 1995] \\
\hline Orthogneiss & $\mathrm{U}-\mathrm{Pb} \mathrm{Zr}$ & $1700-1500$ & Intrusion & [Sheraton et al., 1995] \\
\hline Gneiss & $\begin{array}{l}\mathrm{Sm}-\mathrm{Nd}\left(\mathrm{T}_{\mathrm{DM}}\right) \\
\mathrm{U}-\mathrm{Pb} \mathrm{Zr}\end{array}$ & $\begin{array}{l}2400-2000 \\
3000-2400\end{array}$ & $\begin{array}{l}\text { Magmatism, } \\
\text { primary crust formation }\end{array}$ & [Sheraton et al., 1992, 1995] \\
\hline \multicolumn{5}{|c|}{ Windmill Islands } \\
\hline Gneiss & $\mathrm{U}-\mathrm{Pb} \mathrm{Zr}(\mathrm{SH})$ & $\sim 1200$ & Metamorphism & [Post et al., 1997] \\
\hline Orthogneiss & $\mathrm{U}-\mathrm{Pb} \mathrm{Zr}(\mathrm{SH})$ & $1340-1310$ & $\begin{array}{l}\text { Syntectonic intrusion, } \\
\text { metamorphism, deformation }\end{array}$ & [Post et al., 1997] \\
\hline Gneiss & U-Pb Zr (SH) & 2500 & Magmatism (?) & [Post et al., 1997] \\
\hline \multicolumn{5}{|l|}{ Phanerozoic mobile belt } \\
\hline \multicolumn{5}{|l|}{ Transantarctic Mountains } \\
\hline M-, I-, and S-type granites & $\begin{array}{l}\text { U-Pb Zr, } \\
\text { Rb-Sr WR }\end{array}$ & $540-480$ & Intrusion & $\begin{array}{l}\text { [Adams, 1996; } \\
\text { and many other authors] }\end{array}$ \\
\hline Felsic schist & Rb-Sr WR & $\sim 540$ & Metamorphism & {$[$ Stump, 1995] } \\
\hline Metamorphic rocks & $\mathrm{Sm}-\mathrm{Nd}\left(\mathrm{T}_{\mathrm{DM}}\right)$ & $1700-1300$ & Primary crust formation & [Borg et al., 1990] \\
\hline Orthogneiss & $\mathrm{Pb}-\mathrm{Pb} \mathrm{Zr}$ & 1700 & $\begin{array}{l}\text { Syntectonic intrusion, } \\
\text { deformation }\end{array}$ & [Goodge et al., 1991] \\
\hline Orthogneiss & $\mathrm{Sm}-\mathrm{Nd}\left(\mathrm{T}_{\mathrm{DM}}\right)$ & $2900-2700$ & Primary crust formation & [Borg et al., 1990] \\
\hline \multicolumn{5}{|c|}{ Haag nunatak } \\
\hline Gneiss & $\mathrm{K}-\mathrm{Ar} \mathrm{Hbl}$ & $\sim 1000$ & Metamorphism, deformation & [Clarkson and Brook, 1977] \\
\hline Gneiss & $\mathrm{Sm}-\mathrm{Nd}\left(\mathrm{T}_{\mathrm{DM}}\right)$ & $1600-1300$ & Primary crust formation & [Pankhurst et al., 1988] \\
\hline
\end{tabular}

Note. $\mathrm{SH}=\mathrm{SHRIMP} ; \mathrm{Zr}=$ zircon, $\mathrm{Hbl}=$ hornblende; $\mathrm{WP}=$ whole-rock analysis. 


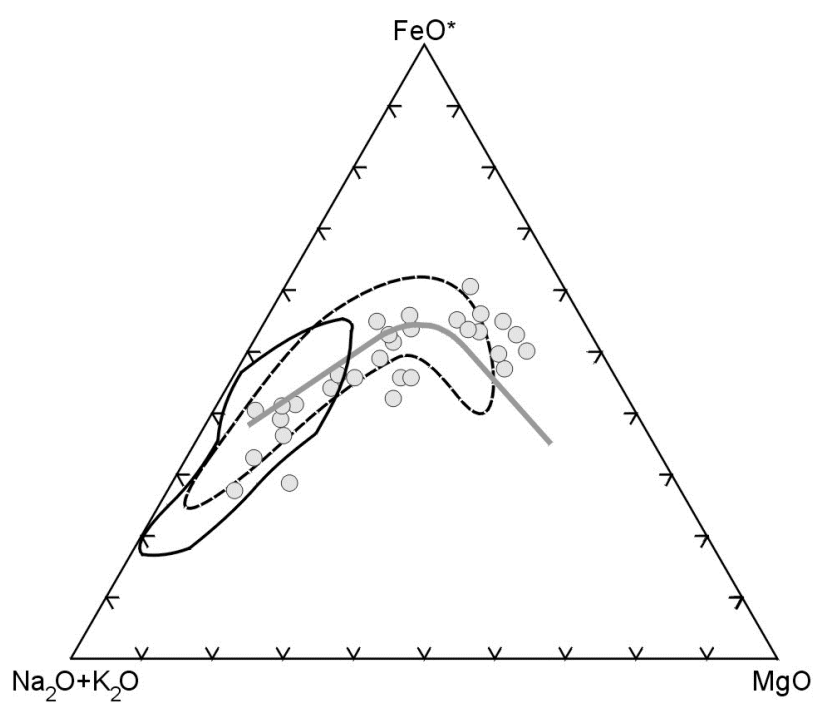

Figure 4. Positions of the metamorphic rocks of the Fisher Complex (circles) and of the orthogneisses from central Queen Maud Land (solid line) and from the Sör Ronnane Mountains (dash line) in the AFM diagram. The solid gray line divides the calc-alkalic and tholeiitic rocks.

The granulite-facies rocks from the Kemp Coast and the Mawson Coast (Rayner Complex) are represented by felsic orthogneisses (of medium and acid composition), banded paragneisses, and mafic granulites. The ages of the key tectonic and thermal processes in this region were found by the SHRIMP method to be as follows: $995 \mathrm{Ma}$ for the amphibolite- to granulate-facies metamorphism, $990 \mathrm{Ma}$ for the granite emplacement, 990-960 Ma for the retrograde metamorphism, synchronous with charnockite emplacement 985 and $955 \mathrm{Ma}$ ago [Young and Black, 1991], and 920$910 \mathrm{Ma}$ for the thermal metamorphism and plastic deformation [Dunkley, 1998]. Some earlier studies indicated that this territory had been underlain over a significant area by a sialic material, as old as $3 \mathrm{Ga}$ [Crew et al., 1988]. The rocks of the Rayner Complex include in some areas the reworked blocks of Archean material. The rocks from the Kemp Coast were dated 3000-2700 Ma. The xenoliths from the metamorphic rocks (charnockites) of the Mawson Coast were found to contain zircons dated 2000-1700 and 1500-1000 Ma.

The central and northern parts of the Prince Charles Mountains are composed of the mainly granulite-facies rocks of the Beaver Complex and, to a lesser extent, of the epidoteamphibolite-facies rocks of the Fisher Complex [Ivanov and Kamenev, 1990]. It is supposed that the oldest rocks in this region are the metamorphics of the Beaver Complex with the $\mathrm{T}_{\mathrm{DM}}$ model ages of $2.2-1.5$ Ga [Manton et al., 1992; Zhao et al., 1997]. The orthogneisses of the Beaver Complex include mainly Bt-Opx tonalite, granodiorite, and granite varieties. Their $\mathrm{Rb}-\mathrm{Sr}$ isochron ages range between $769 \pm 36$ and $1033 \pm 85 \mathrm{Ma}$ [Tingey, 1991], yet, they seem to record some partial or complete re-equilibration during the metamorphism of the Grenville epoch. The tectonic and metamorphic processes operated mainly in the time interval of 990-900 million years [Boger et al., 2000]. The mag- matic rocks of this age (granitoids, pegmatites) are mostly intracrustal formations.

The Fisher Complex consists mainly of felsic and mafic crystalline schists (metavolcanics?) which are comparable chemically with basalts, basaltic andesites, andesites, dacites, and rhyodacites, the basalts being predominant rocks, and also with numerous basic and acid intrusive rocks [Mikhalsky et al., 1996]. The age of the emplacement of the early volcanics is roughly 1300 million years [Beliatsky et al., 1994; Kinny et al., 1997]. The metamorphic rocks occur as a calc-alkalic series (Figure 4) with the geochemical features of their origin in the environment of volcanic/magmatic arcs. Some of these features are a distinct $\mathrm{Nb}$ anomaly and an insignificant positive $\mathrm{Sr}$ anomaly with a moderate enrichment in large-ion microcomponents and the relatively smooth lines of the mormalized contents (Figure 2B). The felsic rocks of the Fisher Complex are comparable mostly with orogenic granitoids (Figure 2), some of them having the compositions similar to the rocks of a tonalite-trondhjemitegranodiorite association. It is believed that the compositions of the metavolcanics and cogenetic intrusive rocks reflect the evolution of a magmatic arc that developed on the continental crust, although some effect of a primitive oceanic lithosphere is inferred from some geochemical evidence (in particular, $\left.\varepsilon_{\mathrm{Nd}(\mathrm{i})}=+2-3, \mathrm{Sr}_{\mathrm{i}}=0.703-0.706\right)$. The model Sm$\mathrm{Nd}$ age of the rocks $\left(\mathrm{T}_{\mathrm{DM}}\right)$ was reported to be $1.6-1.4 \mathrm{Ga}$ [Mikhalsky et al., 1996]. The age of the metamorphism and of the supposedly main deformation phase in this region was dated 1250-1200 Ma. The rocks are believed to have experienced some thermal effects roughly 1100, 1000, and 800 million years ago without any substantial plastic deformation.

The coast of the Pryuds Gulf is composed mainly of paraand orthogneisses of the granulite facies of metamorphism. On the Rauer Islands, almost synchronous with the metamorphic processes were the intrusions of orthogneisses of granite $(1027 \pm 27)$, monzodiorite $(1000 \pm 37)$, and leucogranite $(998 \pm 18)$ composition (all SHRIMP after [Kinny et al., 1993]) and of intracrustal origin. In the Larcemann Oasis the highly aluminiferous schists and orthogneisses underwent repeated plastic deformation and polymetamorphism. It is believed that the high-pressure rocks ( 5 to $12 \mathrm{kbar}$ ) experienced penetrative schistosity and mineral lineation. The isotopic and geochemical data available show that the last stages of deformation and magmatism can be dated Panafrican. The intrusion of synkinematic garnet-bearing (S-type) granite gneisses was dated $547 \pm 9$ and $531 \pm 8$ million years ago [Zhao et al., 1995]. Similar dates were obtained using clastic zircons from the paragneisses of the same area. On this basis some investigators suggest the Pan-African age of sedimentation for some rock sequences. Post-tectonic granites of the A type having a Panafrican age are widely distributed in this area. The model $\mathrm{Sm}-\mathrm{Nd}$ age of the rocks $\left(\mathrm{T}_{\mathrm{DM}}\right)$ in the Pryuds Gulf area is usually $2.2-1.6 \mathrm{Ga}$, though there are some localities where the rocks showed $\mathrm{T}_{\mathrm{DM}}$ ranging between 3.3 and 3.1 billion years [Kinny et al., 1993; Zhao et al., 1995].

The rocks that are roughly comparable with the those of the Beaver and Rayner complexes are developed in the area of the Denman Glacier and Bunger Oasis. This area is 
composed predominantly of orthogneisses and paragneisses of the granulite facies and of mafic granulites cut by various syn- and post-tectonic granitoids. The crystallization of the earliest orthogneisses of a granodiorite composition has been dated 1700-1500 Ma. Yet, some magmatic events were found to be Late Archean (3000-2650 Ma) [Sheraton et al., 1992]. Peak metamorphic events were accompanied by intense plastic deformation. These processes have been dated $1190 \pm 15 \mathrm{Ma}$ [Sheraton et al., 1995].

Numerous plutonic, mainly felsic rocks were intruded synchronously with the final periods of tectonic activity about 1170 and 1150 million years ago. The model Sm-Nd ages of the rocks $\left(\mathrm{T}_{\mathrm{DM}}\right)$ and their relict zircon datings range between 2.4 and $2.0 \mathrm{Ga}$, occasionally being $1.7-1.6$ or older than $2.5 \mathrm{Ga}$ [Sheraton et al., 1992, 1995]. Most of the earliest orthogneisses belong to a Na tonalite-trondhjemitegranodiorite-gneiss association. The latest phases of the silicic plutonites are quartz monzodiorites recording the magmatism of mature magmatic arcs. The rocks of this association are dominated by metaaluminiferous varieties with low $\mathrm{Y}$ and $\mathrm{Nb}$ contents and high normalized Sr contents. As reported by Sheraton and Black [1983] and Sheraton et al. [1985], the low Y content owes its origin to the presence of hornblende and/or garnet as a restite phase in the compositionally mafic substratum. Also exposed in this area is a sequence of poorly metamorphosed sedimentary and volcanic rocks (Sandou Group: sandstones, conglomerates, argillites, and metabasalts), inferred to be of Early Paleozoic age. There are also Pan-African A-type granitoids and alkalic mafic dikes.

The Windmill Islands are composed of deeply metamorphosed quartz-feldspar plagiogneisses, metasedimentary rocks, mafic schists, migmatites, and calciphyres. The intrusion of felsic orthogneisses coincided in time with the zonal metamorphism of amphibolite to granulite facies and with plastic deformation during a period of 1340-1310 million years. Repeated metamorphism and deformation took place also at the boundary between 1210 and 1180 million years, when it was accompanied by granitoid intrusion, and at the time of 1070 million years [Post et al., 1997]. Based on some relict zircon datings, the age of the crust in this area is estimated to be Late Archean ( $>2.5$ billion years).

\section{Geodynamics of Meso-Neoproterozoic and Early Paleozoic Tectonic Activity}

As follows from the data discussed above, some regions of East Antarctica experienced plastic deformation and amphibolite-granulite facies metamorphism during a period of time between the Meso- and Neoproterozoic. The peaks of the tectonic and thermal activity differed in time in various regions, reflecting the polyphase character of the Grenville tectonic activity with its peaks approximately 1200-1100, 1050-1000, and 1000-900 million years ago. The features common for all regions are the voluminous intrusions of plutonic rocks, mainly pre- and syn-tectonic granitoids, although some late- and post-tectonic granitoids are present in some areas. However, only an insignificant amount of the rocks can be interpreted as juvenile mantle products. One of the important criteria of the rock genesis, allowing one to reconstruct the juvenile nature of geologic bodies, is an agreement between the age of the rocks and the model time when their parental material separated from the mantle source $\left(\mathrm{T}_{\mathrm{DM}}\right)$ [DePaolo, 1989].

As follows from the model $\mathrm{T}_{\mathrm{DM}}$ datings available, the continental blocks that were involved in the Mesoproterozoic tectonic activity did not have the same age within the Proterozoic mobile belt (Figure 5). Most of the territory is underlain by the rocks ranging in age between 2.4 and 1.8 billion years, although there are blocks containing a sialic material at least 3.3-2.4 Ga old. Therefore, only a few rock complexes of limited extent, concentrated in the Prince Charles Mountains, in the west of Queen Maud Land and, possibly, in the Sör Ronnane Mountains, with $\mathrm{T}_{\mathrm{DM}}$ values ranging between 1.8 and $1.1 \mathrm{Ga}$, can be interpreted as the juvenile mantle products of Mesoproterozoic age. Elsewhere, the rocks of this age are represented by the products of the destruction and anatexis of the older crustal rocks with a limited amount of mantle products.

Most of the regions include characteristic sodic, low- $Y$ tonalite gneisses which can be correlated with a tonalitetrondhjemite-granodiorite association. However, the amounts of these rocks vary greatly from area to area. For instance, they occur as predominant rocks in the area of the Bunger Oasis and in the Prince Charles Mountains, but are scarce in the central part of Queen Maud Land. The origin of these rocks is still a matter of debate. Most of the investigators interpret them as the indicators of convergence above subduction zones. In fact, some experimental studies [Beard and Lofgren, 1991] confirm the possibility that metaaluminiferous or poorly plumasitic tonalitesgranodiorite magmas can be derived from basic rocks at a moderate partial water pressure. However, other experiments [Wolf and Wyllie, 1994] showed that the source of these magmas could be the garnet-rich rocks of the lower crust (eclogite, garnet amphibolite) during a pressure rise to $10 \mathrm{kbar}$ and "dry" melting. Therefore, the petrogenesis of these rocks could be controlled both by the subduction of amphibolite material (for example, relative to the young oceanic crust) in a system of island and magmatic arcs, and by the processes of mantle upwelling without any significant effects of water and subduction. Since most of the regions did not show any indications of other rock types that might have marked the zone of subduction and/or suturing, the latter hypothesis seems to be more realistic.

In terms of geodynamics, the Proterozoic mobile belt of East Antarctica is a Grenville suture that had originated in the vicinity of a boundary between the Meso- and Neoproterozoic. The most popular view is that this had been caused by the amalgamation of Antarctica and other southern continents into the Rodinia Supercontinent, that is, by the closure of the Mesoproterozoic oceans and the associated subduction and collision events. However, the data available suggest that the more realistic view is that the Grenville tectogenesis in Antarctica was caused primarily by its convergence with the other continents that had been previously separated by vast oceanic spaces. 


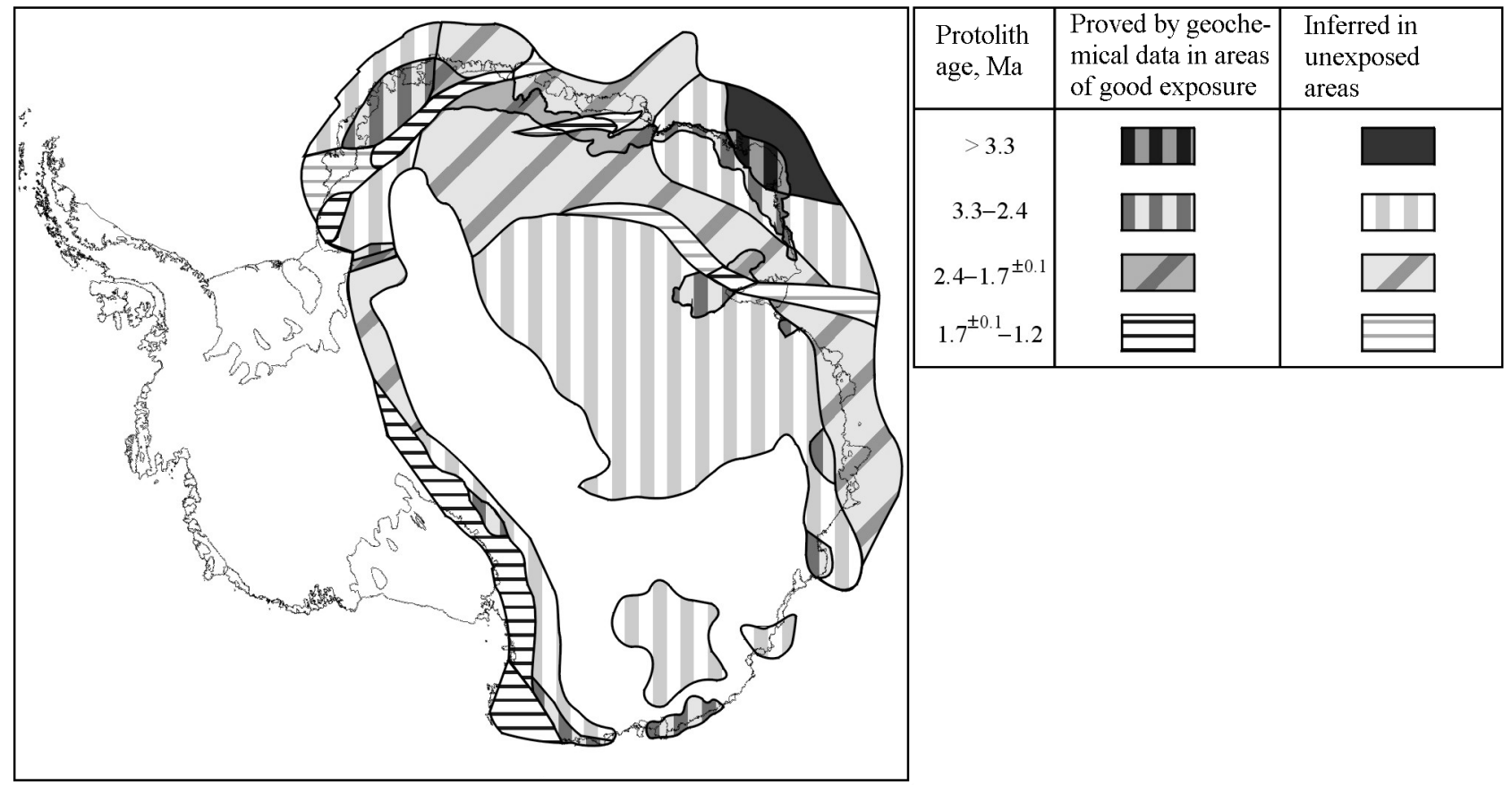

Figure 5. Map of East Antarctica showing the regions with the Earth crust of different ages $\left(T_{D M}\right.$ based on the relict $\mathrm{U}-\mathrm{Pb}$ datings of zircons in some areas, after our own and literature data).

We believe it to be more likely that the beginning with the Early Precambrian Antarctica and its southern neighbors had been parts of some supercontinent which experienced extension roughly during the middle or end of the Mesoproterozoic with the formation of a system of weak zones existing as intracontinental rifts. It is likely that these rifts varied in the degree of the extension and reworking of the continental crust, yet most of them (at least those in the Antarctic block) did not experience any breakup and substantial spreading. The potential exception was the region of the Shackleton Range, where high-pressure eclogite-like rocks and ultramafics (ophiolite complex) have been dated roughly 1000 to 500 million years [Talarico et al., 1999], and also the central part of the Prince Charles Mountains, the Sör Ronnane Mountains, and the western part of Queen Maud Land. However, even taking into account these examples of the local participation of an oceanic substrate in the formation of the Grenville suture, we believe its origin to be mainly ensialic, that is, caused mainly by the extension and compression of the continental lithosphere without its complete breakup. It seems likely that during the Grenville Cycle this huge continental massif experienced first rifting with some spreading elements, but did not break up, and, conversely, reconstructed its integrity through the "welding" of the weakened rift sutures. Therefore, we believe that the predominant environments during the Grenville epoch were thrust and strike-slip fault movements with the predominance of a transtensive component during the extension and of a transpressive component during the compression. However, the subduction component of the Grenville orogenesis should be assumed for some segments of the mobile belt.

To sum up, the Proterozoic mobile belt was a long-lived source of ensialic tectonic activity which concentrated, after the Early Precambrian stabilization of the granulite-gneiss and granite-greenstone regions, in the intercratonic spaces of the ancient proto-supercontinent. In these zones, the primary continental lithosphere might have experienced, during a significant period of the Proterozoic (up to a boundary between the Precambrian and Phanerozoic), pulse-like extensions which might have caused local oceanic opening but did not result in the complete breakup of the sialic megablock with the initial drift of its fragments or spreading development. On the contrary, according to the data available, the sutures weakened by extension were "healed", and the full-scale orogenesis developed with the elements of collision piling and deep anatexis.

Geologic formations, comparable in composition and tectonic and thermal evolution, are developed on the Haag nunataks in West Antarctica, and also on the Falkland Islands and in the Namakua-Natal Province of South Africa, where the respective tectonic processes have been recognized as the Kibarian Orogeny. An almost identical geologic history has been recognized in the Albany-Fraser Province in Southwest Australia.

According to a popular view, the post-Grenville Rodinia experienced during the Neoproterozoic a complete disintegration with the formation of several isolated continents and large oceans separating them. During the Paleozoic these land masses are believed to have been amalgamated again to produce a new supercontinent, Gondwana [Rogers et al., 1995]. However, the data available for Antarctica do not agree with this hypothesis. No sedimentary rocks of Middle Neoproterozoic age (900-600 million years) have been found in the East Antarctica Shield. The only indirect evidence of 
sedimentation on the coast of the Lützow-Hölm Gulf and in the area of the Larcemann Oasis are clastic zircons with the relict age of $1000 \mathrm{Ma}$ in paragneiss. This suggests that sedimentation, at least partial, might have taken place in these areas during the (Middle?) Neoproterozoic time. Igneous rock occurrences are limited by the small bodies of granitoid/pegmatite and orthogneiss on Enderbi Land (760-720 mln. yr.) and in the Shirmaher Oasis (700 mln. yr.), respectively. The tectonothermal activity of this age, discovered by isotopic methods in Antarctica, was found to be comparatively weak. $\mathrm{U}-\mathrm{Pb}$ studies (relict indications of the matter from SRIMP data or individual concordant populations of zircons) and $\mathrm{Sm}-\mathrm{Nd}$ data for monomineral fractions point to thermal events with the ages of 850-600 Ma in the Prince Charles Mountains, in the Grove nunataks, in the Larcemann Oasis, and in Enderbi Land. However, these dates have not been correlated with any geological processes, and seem to be of thermal rather than tectonic origin.

To sum up, the data available do not allow us to interpret the Middle Proterozoic stage as the time of the breakup of the Antarctic lithospheric block, which had been a part of the Rodinia Supercontinent, into individual fragments, in spite of this hypothesis being very popular in modern literature.

The Pan-African (600-500 Ma) phase of tectogenesis manifested itself in some or other extent over the larger part of East Antarctica. The only exceptions are Wilkes Land and some areas in the west of Queen Maud Land. In some areas, igneous rock bodies were intruded (anorthosite, charnockite, A-type granitoids, mafic and lamprophyre dikes, pegmatite bodies), and sedimentary rocks accumulated in limited amounts (Urfjella Group and Sandow Group), yet spatially thermal activity was predominant in some areas (reequilibration of $\mathrm{Rb}-\mathrm{Sr}$ and $\mathrm{K}-\mathrm{Ar}$ mineral systems), as well as local metamorphism (amphibolite to granulite facies) and plastic deformation.

Until recently, the numerous Pan-African isotope dates (K-Ar and Rb-Sr) derived in the 1960-1970s for the majority of East Antarctic regions were interpreted as the results of an active thermal process which was believed to have been accompanied by insignificant deformation [Grikurov, 1980; Ravich et al., 1965; Tingey, 1991; and others]. However, at the present time it can be taken as a proved fact that in some areas tectonic activity was intensive enough to involve penetrating schistosity, metamorphism, and plastic deformation. The epicenters of the Pan-African tectonic activity were the central parts of Queen Maud Land, the Lützow-Holm Gulf coast, and the Larsemann Oasis.

However, no obvious traces of any large-scale Early Paleozoic convergence with the closure of the oceanic basins have been found. Although some small massifs of (intraplate) synkinematic orthogneiss and granite are inferred in some local areas, any notable amounts of sialic matter had not been formed. On the contrary, the Early Paleozoic peak had been mostly associated with the intrusive manifestations of tectonic and thermal activity which involved the structural reworking and repeated metamorphism of the enclosing Grenville rocks. The main phase of the Pan-African deformation in Queen Maud Land can be interpreted as the intraplate response of the oblique collision of large conti- nental blocks, which had taken place in the more northern regions.

It should be noted that the collision regime proper, with the closure of the ocean basin, persisted in the significantly more northern regions, this being proved by the real structural rock complexes in Central and North Africa, in the northern segment of the Mozambique Belt [Shackleton, 1993]. This region is characterized by a "soft" arc-continent collision, which was superseded by a continent-continent collision 600 million years ago [Shackleton, 1996]. Developed here are ophiolites and accretion-type rocks which underwent greenschist and low-grade amphibolite metamorphism. The tectonic and thermal evolution of the more southern segments of the Mozambique Belt resembles that of the Queen Maud Land. The southern segment of the Mozambique Belt is composed mostly of Mesoproterozoic rocks reworked in a varying degree by Pan-African tectonic activity. This stage was distinguished by the plastic deformation and deep metamorphism of the rocks, and by granite intrusion. This stage has been dated 500 million years [Kröner, 1993]. The major tectonic structures of the southern segment of the Mozambique Belt include thick mylonite zones [Jacobs and Thomas, 1996] which can be interpreted as the indications of the oblique collision of the continental blocks (?) in the NW direction along the submeridionally oriented margin. Therefore the data available preclude the assumption that a significant oceanic basin existed during the Pan-African stage between the megablocks of West and East Gondwana. It is more likely that these territories existed as one continental block beginning from the end of the Mesoproterozoic. During the Pan-African epoch this region experienced some "echoes" of the powerful collision processes, recorded in the northern segment of the Mozambique Belt and imprinted in Antarctica as transcurrent, longitudinally compressional and locally longitudinally spreading tectonic movements, as intraplate granitoid intrusions, and as the widely manifested $\mathrm{K}-\mathrm{Ar}$ and $\mathrm{Ar}-\mathrm{Ar}$ reequilibration of the mineral isotope systems. This reequilibration of the isotope systems might have been associated with the release of much heat during the tectonic movements, or with the additional heat produced by the underplating of mafic materials at the base of the Earth crust.

\section{Conclusion}

The popular view of foreign investigators that Gondwana was formed of the fragments of the Rodinia Mesoproterozoic Continent does not seem to be convincing, as follows from the evidence available for Antarctica. The isotopic and geochemical characteristics of the metamorphic rocks attributed to the Proterozoic mobile belt of the East Antarctic crystalline basement with its epicenters of Proterozoic and Early Paleozoic tectonic activity includes two distinct dating peaks in the intervals of 1400-900 and 600-500 million years, which correlated with the Grenville and Pan-African peaks of tectonic activity. There is also a fairly wide spectrum of older age markers. The model $\mathrm{Sm}-\mathrm{Nd}$ (DM) dates and the relict components of the $\mathrm{U}-\mathrm{Pb}$ systems of zircons suggest that 
in most cases the Grenville tectonic activity involved some older initial continental material. This allows one to consider the East Antarctic grenvillides as mainly supracrustal metamorphic sedimentary and sedimentarysvolcanic rock sequences or as orthogneiss rocks of intraplate origin. It is only in some areas (western part of Queen Maud Land, Sör Ronanne Mountains, and the central part of the Prince Charles Mountains) that one can find evidence of some accretionary growth of the Earth's crust. The Pan-African events inherited spatially the propagation of the grenvillides and consisted, actually, in their tectonic and thermal rejuvenation. The intensity of the Early Paleozoic tectonic activity was locally as high as granulite-facies metamorphism (the central part of Queen Maud Land and the costal parts of the Lützov-Holm and Pryuds gulfs), yet mainly that was the highly intense intrusive magmatism which was also primarily of the intraplate type.

Summing up, we can offer the following conclusions:

1. The Proterozoic (Grenville) mobile belt of Antarctica is largely of ensialic origin; its evolution was controlled mainly by the extension and compression of the continental lithosphere without its complete disruption. Some segments of the mobile belt show the subduction constituent of the Grenville orogeny, though its role in the total tectogenesis seems to have been limited.

2. Antarctica was a continental mass which experienced a more or less coherent evolution as one whole beginning from the end of the Mesozoic. No evidence of the disintegration or breakup of the continental mass has been found.

3. The Pan-African tectonic and magmatic activity was mainly the intraplate, intracrustal reflection of the collisions of the continental blocks during the formation of Gondwana (outside of Antarctica); the Antarctic Grenvillides were severely affected by the Pan-African tectonic and magmatic activity.

\section{References}

Adams, C. J., Geochronological evolution of Northern Victoria Land: Rb-Sr and K-Ar dating of the Berg Group and Berg/Archangel granites, in Roland, N. W. (Ed.), German Antarctic North Victoria Land Expedition GANOVEX from Oates Coast to Marie Byrd Land, Geologisches Jahrbuch, Reiche B, Heft 89, 179-194, 1996.

Beard, J. S., and G. E. Lofgren, Dehydration melting and watersaturated melting of basaltic and andesitic greenstones and amphibolites at 1, 3, and $6.9 \mathrm{~kb}, J$. Petrol., 32, 365-401, 1996.

Beliatsky, B. V., A. A. Laiba, and E. V. Mikhalsky, U-Pb zircon age of the metavolcanic rocks of Fisher Massif (Prince Charles Mountains, East Antarctica), Antarctic Science, 6, 355-358, 1994.

Boger, S. D., C. J. Carson, C. J. L. Wilson, and C. M. Fanning, Neoproterozoic deformation in the Radok Lake region of the Northern Prince Charles Mountains, East Antarctica: Evidence for a single protracted orogenic event, Precambrian Res., 104, 1-24, 2000.

Borg, S. G., D. J. DePaolo, and B. M. Smith, Isotopic structure and tectonics of the Central Transantarctic Mountains, J. Geophys. Res., 95, 6647-6667, 1990.

Brommer, A., I. L. Miller, and A. Zeh, Geochronology, structural geology, and petrology of the northwestern La Grange nunataks, Shackleton Range, Antarctica, Terra Antarctica, 6, 269-278, 1999.
Clarkson, P. D., and M. Brook, Age and position of the Ellsworth Mountains crustal fragment, Antarctica, Nature, 265, 615-616, 1977.

Dalziel, L. W. D, Pacific margins of Laurentia and East Antarctica -Australia as a conjugate rift pair: Evidence and implications for an Eocambrian Supercontinent, Geology, 19, (6), 598-691, 1991.

DePaolo, D. J., Neodymium Isotope Geochemistry, SpringerVerlag, 181 p., 1989.

Dunkley, D. J., The Reyner Complex in MacRobertson Land, Unpublished PhD Thesis, University of Sydney, 1998.

Egiazarov, B. H. (Ed.), Tectonic map of the Polar Regions of the Earth, scale 1:0000000, USSR Ministry of Geology, Moscow, 1969.

Goodge, J. W., S. G. Borg, B. K. Smith, and V. C. Bennett, Tectonic significance of Proterozoic ductile shortening and translation along the Antarctic margin of Gondwana, Earth Planet. Sci. Lett., (102), 58-70, 1991.

Gose, W. A., M. A. Helper, J. N. Connelly, et al., Paleomagnetic data and $\mathrm{U}-\mathrm{Pb}$ isotope age determinations from Coats Land, Antarctica: Implications for the Late Proterozoic plate reconstructions, J. Geophys. Res., 102, 7887-7902, 1997.

Grantham, G. H., C. Jackson, B. M. Eglington, et al., Isotopic relocation of the Kaapvaal Craton margin in Antarctica with implications for the tectonic fabric of western Dronning Maud Land, 8th International Symposium on Antarctic Earth Sciences, Wellington, Abstract Volume, p. 126, 1999.

Grew, E. S., W. I. Manton, and P. R. James, U-Pb data on granulite facies rocks from Fold Island, Kemp Coast, East Antarctica, Precambrian Res., 42, 63-75, 1988.

Grikurov, G. E. (Ed.), Tectonic Map of Antarctica, scale 1:0000000, 1978.

Grikurov, G. E. (Ed.), Explanatory Note to Tectonic Map of Antarctica, scale 1:0000000, NIIGA, Leningrad, 1980.

Groenewald, P. B., A. B. Moyes, G. H. Grantham, and J. R. Krynauw, East Antarctic crustal evolution: Geological constraints and modelling in western Dronning Maud Land, Precambrian Res., 75, 231-250, 1995.

Harris, P. D., A. B. Moyes, C. M. Fanning, and R. A. Armstrong, Zircon and microprobe results from the Maudheim high-grade gneiss terrane, western Dronning Maud Land, Centennial Geocongress, Geol. Soc. South Africa, extended abstracts, 240242, 1995.

Hoffman, P. F., Did the breakout of Laurentia turn Gondwanaland inside out?, Science, 252, 1409-1412, 1991.

Hunter, D. R., J. R. Krynauw, et al., A recent history of South Africa earth science research in Antarctica and adjacent regions, S. Afr. J. Antarct. Res., 21, (2), 173-183, 1991.

Jacobs, J., and R. J. Thomas, Pan-African rejuvenation of the c.1.1 Ga Natal Metamorphic Province (South Africa): K-Ar muscovite and titanite fission track evidence, J. Geol. Soc. London, 153 971-978, 1996.

Jacobs, J., H. Ahrendt, H. Kreutzer, and K. Weber, K-Ar 40, Ar39 , and apatite fission-track evidence for Neoproterozoic and Mesozoic basement rejuvenation events in the Heimefrontfjella and Mannefallknausane (East Antarctica), Precambrian Res., 75, 251-262, 1995.

Jacobs, J., M. Falter, K. Weber, and E. K. Jessberger, ${ }^{40} \mathrm{Ar}-$ ${ }^{39} \mathrm{Ar}$ evidence for the structural evolution of the Heimefront shear zone (Western Dronning Maud Land), East Antarctica, in The Antarctic Region: Geological Evolution and Processes, Ricci C. A. (Ed), 31-37, TerraPub, Siena, 1997.

Jacobs, J., C. M. Fanning, F. Henjes-Kunst, et al., Continuation of the Mozambique Belt into East Antarctica: Grenville-age metamorphism and polyphase Pan-African high-grade events in central Dronning Maud Land, J. Geol., 106, 385-406, 1998.

Jacobs, J., C. M. Fanning, F. Henjes-Kunst, M. Olesch, and H.-J. Paech, Continuation of the Mozambique Belt into East Antarctica: Grenville-Age metamorphism and polyphase PanAfrican high-grade events in Central Dronning Maud Land, Abstr., 8th Intern. Symp. on Antarctic Earth Sciences, p. 155, Wellington, 1999.

Ivanov, V. L., and E. N. Kamenev, Geology and Mineral Re- 
sources of Antarctica, Nedra, Moscow, 1990.

Kamenev, E. N., Structure and evolution of the Antarctic Shield in Precambrian, in: Findley, R. H., Unrug, R., Banks, M. R. and Veevers, J. J. (Eds.), Gondwana-8: Assembly, Evolution and Dispersal, Rotterdam: Balkema, 141-151, 1993.

Kämph, H., and A. Höhndorf, Geochronologie Wohlthat Massiv, 48 p., Antarktika, Unpublished DFG Report, 1995.

Kinny, P. D., L. P. Black, and J. W. Sheraton, Zircon ages and the distribution of Archaean and Proterozoic rocks in the Rauer Islands, Antarctic Science, 5, 193-206, 1993.

Kinny, P. D., L. P. Black, and J. W. Sheraton, Zircon U-Pb ages and geochemistry of igneous and metamorphic rocks in the northern Prince Charles Mountains, Antarctica, AGSO Journal of Australian Geology and Geophysics, 16, 637-654, 1997.

Klimov, L. V., M. G. Ravich, and D. S. Soloviev, Geological structure of the Antarctic Craton, in Papers of the Commission on Antarctica, 9-20, 1964.

Kröner, A., The Pan-African belt of Northeast and East Africa, Madagascar, southern India, Sri Lanka, and East Antarctica: Terrane amalgamation during the formation of Gondwana Supercontinent, in Geoscientific Research in North Africa, U. Thorwihe and H. Schandelmeier (Eds.), pp. 3-9, Rotterdam, Balkema, 1993.

Manton, W. I., E. S. Grew, J. Hofmann, and J. W. Sheraton, Granitic rocks of the Jetty Peninsula, Amery ice shelf area, East Antarctica, in Recent Progress in Antarctic Earth Sciences, Yoshida, Y., Kaminuma, K., and Shiraishi, K. (Eds.), pp. 179-189, TerraPub, Tokyo, 1992.

Mikhalsky, E. V., J. W. Sheraton, A. A. Laiba, and B. V. Beliatsky, Geochemistry and origin of Mesoproterozoic metavolcanic rocks from Fisher Massif, Prince Charles Mountains, East Antarctica, Antarctic Science, 8, 85-104, 1996.

Mikhalsky, E. V., B. V. Beliatsky, E. V. Savva, et al., Reconnaissance geochronologic data on polymetamorphic and igneous rocks of the Humboldt Mountains, central Queen Maud Land, East Antarctica, in The Antarctic Region: Geological Evolution and Processes, Ricci, C. A. (Ed.), pp. 45-53, Terra Antarctica Publ., Siena, 1997.

Moyes, A. B., and J. M. Barton, Jr., Review of isotopic data from western Dronning Maud Land, Antarctica, Zentralblatt fur Geologie und Paläontologie, Teil I, (1/2), 19-31, 1990.

Osanai, Y., K. Shiraishi, Y. Takanashi, et al., Geochemical characteristics of metamorphic rocks from the Central Sör Ronnane Mountains, East Antarctica, in Recent Progress in Antarctic Earth Science, Yoshida, Y., Kaminuma, K., and Shiraishi, K. (Eds.), pp. 17-28, TerraPub, Tokyo, 1992.

Pankhurst, R. J., P. D. Marsh, and P. D. Clarkson, A geochronological investigation of the Shackleton Range, in Antarctic Earth Science, Oliver, R. L., James, P. R., and Jago, J. B. (Eds.), pp. 176-182, Australian Academy of Science and Cambridge University Press, Canberra, 1983.

Pankhurst, R. J., M. J. Hole, and M. Brook, Isotope evidence for the origin of Andean granites, Royal Soc. Edinburgh Philos. Trans., 79, 123-133, 1988.

Pankhurst, R. J., H. Kreuzser, A. Hohndorf, and B. Belyatsky, Geochronology, in Geological map of Shackleton Range, Antarctica, Clarkson, P. D., Tessensohn, F., Thomson, J. W., et al., pp. 53-56, British Antarctic Survey, GEOMAP Series, Sheet 4, with supplementary text, BAS, Cambridge, 1995.

Post, N. J., B. J. Hensen, and P. D. Kinny, Two metamorphic episodes during a 1340-1180 Ma convergent tectonic event in the Windmill Islands, East Antarctica, in Antarctic Region: Geological Evolution and Processes, Ricci, C. A. (Ed.), pp. 157162, TerraPub, Siena, 1997.

Ravich, M. G., and G. E. Grikurov, Basic features of the Antarctic tectonics, Sov. Geol., (1), 12-27, 1970.

Ravich, M. G., L. V. Klimov, and D. S. Soloviev, The Precambrian of East Antarctica, 469 pp., Nedra Press, Moscow, 1965.

Rogers, J. W., R. Unrug, and M. Sultan, Tectonic assembly of Gondwana, J. Geodynamics, 19, 1-34, 1995.

Shackleton, R. M., Tectonics of the Mozambique Belt in East Africa, in Precambrian Processes and Plate Tectonics,
Pritchard, H. M., et al. (Eds.), pp. 345-362, Geol. Soc. Spec. Publication 76, 1993.

Shackleton, R. M., The final collision zone between East and West Gondwana: Where is it?, J. Afr. Earth Sci., 23, 271-287, 1996.

Sheraton, J. W., and L. P. Black, Geochemistry of Precambrian gneisses: Relevance for the evolution of the East Antarctic Shield, Lithos, 16, 273-296, 1983.

Sheraton, J. W., D. J. Ellis, and S. M. Kuehner, Rare-earth element geochemistry of Archaean gneisses and the evolution of the East Antarctic Shield, BMR J. Austral. Geology and Geophysics, 9, 207-218, 1985.

Sheraton, J. W., L. P. Black, and A. G. Tindle, Petrogenesis of plutonic rocks in a Proterozoic granulite-facies terrane - the bunger hills, East Antarctica, Chem. Geol., 97, 163-198, 1992. Sheraton, J. W., R. J. Tingey, R. L. Oliver, and L. P. Black, Geology of the Bunger Hills - Denman Glacier region, East Antarctica, Austral. Geol. Surv. Organ. Bull., 244, 1995.

Shibata, K., K. Yanai, and K. Shiraishi, Rb-Rb whole-rock ages of metamorphic rocks from eastern Queen Maud Land, East Antarctica, Mem. National Inst. of Polar Research, Tokyo, 43, 133-148, 1986.

Shiraishi, K., and H. Kagami, Sm-Nd and Rb-Sr ages of metamorphic rocks from the Sör Rondane Mountains, East Antarctica, in Recent Progress in Antarctic Earth Science, Yoshida, Y. Kaminuma, K, and Shiraishi, K., Eds., pp. 29-35, Terra Sci. Publ. Company, Tokyo, 1992.

Shiraishi, K., Y. Hiroi, D. J. Ellis, et al., The first report of a Cambrian orogenic belt in East Antarctica - an ion microprobe study of the Lützow-Holm Complex, in Recent Progress in Antarctic Earth Science, Yoshida, Y., Kaminuma, K., and Shiraishi, K. (Eds.), pp. 67-73, Terra Sci. Publ. Company, 1992.

Stump, E., Ross Orogen of the Transantarctic Mountains, 284 p., Cambridge Univ. Press, New York, 1995.

Sun, S-S., and W. F. McDonough, Chemical and isotopic systematics of ocean basalts: Implications for mantle composition and processes, in Magmatism in Ocean Basins, Saunders, A. D. and Norry, M. J. (Eds.), Geol. Soc. Spec. Publ., 42, 313-345, 1989.

Talarico, F., G. Kleinschmidt, and F. Heinjes-Kunst, An ophiolitic complex in the northern Shackleton Range, Antarctica, Terra Antarctica, 6, 293-315, 1999

Tingey, R. J., The regional geology of Archaean and Proterozoic rocks in Antarctica, in The Geology of Antarctica, Tingey, R. J. (Ed.), pp. 1-58, Clarendon Press, Oxford, 1991.

Ushakov, S. A., and V. E. Khain, The structure of Antarctica from geological and geophysical data, Vestnik $M G U,(1), 3-27$, 1965.

Voronov, P. S., The structure of Antarctica, in Trudy NIIGA (Trans. Inst. Arctic Geology), 113, 5-24, 1960.

Whalen, J. B., B. W. Currie, and B. W. Chappell, A-type granites: Geochemical characteristics, discrimination, and petrogenesis, Contrib. Mineral. Petrol., 95, 407-419, 1987.

Wareham, C. D., R. J. Pankhurst, R. J. Thomas, et al., Pd, Nd, and $\mathrm{Sr}$ isotope mapping of Grenville-age crustal provinces in Rodinia, J. Geol., 106, 647-659, 1998.

Wolf, M. B., and P. J. Wyllie, Dehydration melting of amphibolite at 10 kbar: Effects of temperature and time, Contrib. Mineral. Petrol., 115, 369-383, 1994.

Young, D. N., and L. P. Black, U-Pb zircon dating of Proterozoic igneous charnockites from the Mawson Coast, East Antarctica, Antarctic Science, 3, 205-216, 1991.

Zhao, Y., X. Liu, B. Song, et al., Constraints on the stratigraphic age of metasedimentary rocks from the Larsemann Hills, East Antarctica: Possible implications for Neoproterozoic tectonics, Precamb. Res., 75, 175-188, 1995.

Zhao, Y-X., D. J. Ellis, J. A. Kirpatrick, and M. T. McCulloch, Geochemical and $\mathrm{Sr}-\mathrm{Nd}$ isotopic study of charnockites and related rocks in the northern Prince Charles Mountains, East Antarctica: Implications for charnockite petrogenesis and Proterozoic crustal evolution, Precambrian Res., 81, 37-66, 1997.

(Received 26 June 2002) 